\title{
Pushing the switch: functional responses and prey switching by invasive lionfish may mediate their ecological impact
}

\author{
Monica McCard (1) - Josie South (1) - Ross N. Cuthbert (D) James W. E. Dickey (1) \\ Nathan McCard · Jaimie T. A. Dick
}

Received: 18 February 2020/ Accepted: 23 January 2021/Published online: 5 March 2021

(C) The Author(s) 2021

\begin{abstract}
Biodiversity is declining on a global scale and the spread of invasive alien species (IAS) is a major driver, particularly through predatory impacts. Thus, effective means of assessing and predicting the consequences of IAS predation on native prey population stability remains a vital goal for conservation. Here, we applied two classic ecological concepts, consumer functional response (FR) and prey switching, to predict and understand the ecological impacts of juveniles of the lionfish (Pterois volitans), a
\end{abstract}

Supplementary Information The online version contains supplementary material available at https://doi.org/10.1007/ s10530-021-02487-7.

M. McCard $(\bowtie) \cdot$ J. South $\cdot$ R. N. Cuthbert .

J. W. E. Dickey · J. T. A. Dick

Institute for Global Food Security, School of Biological

Sciences, Queen's University Belfast, 19 Chlorine

Gardens, Belfast, Northern Ireland BT9 5DL, UK

e-mail: mmccard01@qub.ac.uk

\section{J. South}

Centre for Invasion Biology, South African Institute for Aquatic Biodiversity (SAIAB), Makhanda 6140, South Africa

J. South - R. N. Cuthbert

DSI/NRF Research Chair in Inland Fisheries and Freshwater Ecology Laboratory, South African Institute for Aquatic Biodiversity (SAIAB), Makhanda 6140, South Africa notorious and widespread marine invader. Functional responses and prey switching propensities were quantified towards three representative prey species: Artemia salina, Palaemonetes varians, and Gammarus oceanicus. Lionfish exhibited potentially destabilising Type II FRs towards individual prey species, owing to high consumption rates at low prey densities, whilst FR magnitudes differed among prey species. Functional response attack rates $(a)$ were highest, and handling times $(h)$ lowest, towards A. salina, followed by $P$. varians and then $G$. oceanicus. Maximum feeding rates $(1 / h)$ and functional response ratios (FRR; $a / h$ ) also followed this impact gradient for the

\author{
R. N. Cuthbert \\ GEOMAR Helmholtz Centre for Ocean Research Kiel, \\ Düsternbrooker Weg 20, 24105 Kiel, Germany \\ J. W. E. Dickey \\ Leibniz-Institute of Freshwater Ecology and Inland \\ Fisheries (IGB), 12587 Berlin, Germany \\ N. McCard \\ Environmental Sciences, School of Science and \\ Technology, Bournemouth University, Fern Barrow, \\ Poole, Dorset BH12 5BB, UK
}


three prey species. Lionfish, however, displayed a potentially population stabilising prey switching propensity (i.e. frequency-dependent predation) when multiple prey species were presented simultaneously, where disproportionately less of rare prey, and more of abundant prey, were consumed. Whilst FR and FRR magnitudes indicate marked per capita lionfish predatory impacts towards prey species, a strong prey switching propensity may reduce in-field impacts by offering low density prey refuge in biodiverse communities. Our results thus corroborate field patterns documenting variable impacts of lionfish, with prey extirpations less likely in diverse communities owing to frequency-dependent predation.

Keywords Frequency-dependent predation . Interaction strength · Invader impact prediction . Marine biology $\cdot$ Pterois volitans

\section{Introduction}

The introduction, establishment, and spread of invasive alien species (IAS) presents major threats to biodiversity and economies worldwide (Simberloff et al. 2013; Dick et al. 2017a, b; IPBES 2019; Haubrock et al. 2020), and the rate at which invaders are arriving remains high owing to increasing geographical connectivity (Seebens et al. 2018). Invasive alien species spread has been facilitated by globalised transport networks (Zieritz et al. 2016), and their establishment in new areas is being further aided by changing climates and anthropogenic alterations of ecosystems (Didham et al. 2007; Muhlfeld et al. 2014). Marine coastal systems have become the most heavily invaded regions due to increases in aquaculture, global shipping activities and connectivity, such as the Suez Canal creating a corridor for invasions into the Mediterranean (Briski et al. 2015; Stuer-Lauridsen et al. 2018). Impacts of IAS can be far-reaching, and affect ecosystems, biodiversity, the economy, food security, and human, animal and plant health (Lowry et al. 2013; Cuthbert et al. 2021). With numerous examples of failed attempts at IAS eradication and control (Courchamp et al. 1999; Rayner et al. 2015), consensus is being reached that management focus should lie with prevention, rather than eradication (Piria et al. 2017). However, in order to prioritise actions and allocate limited resources, we need enhanced predictive capacity in invasion ecology, especially to forecast potential ecological impacts (Dick et al. 2017b; Cuthbert et al. 2019a, b).

Predicting invasion patterns and processes could help elucidate future risks posed by IAS towards native species (Ricciardi 2003; Simberloff 2011; 2013; Dick et al. 2014, 2017a). In turn, prediction methods must also be robust when facing combinations of abiotic and biotic environmental drivers or "context-dependencies" (Ricciardi et al. 2003; Alexander et al. 2014). Invasive species generally demonstrate a higher resource use efficiency as compared to native analogues, and this has been linked to their higher ecological impact (Morrison and Hay 2011; Dick et al. 2014, 2017a, b; Cuthbert et al. 2019b). Functional responses (FRs: resource consumption as a function of resource density; Holling 1959) have been used effectively to assess and predict the ecological impacts of invaders (see Dick et al. 2014; Iacarella et al. 2015; South et al. 2017; Cuthbert et al. 2019b). Three types of FR have been described. A Type I response is characterised by a lack of handling time, where consumption rate increases linearly as resource density rises (Jeschke et al. 2014; Hoxha et al. 2018). Hyperbolic Type II responses are characterised by high proportional consumption at low resource densities followed by an asymptote, and are widely regarded as destabilising on resource populations, such as prey species that cannot escape predation when relatively rare (Murdoch and Oaten 1975; Hassell 1978). Conversely, Type III responses, with a sigmoidal curve, are deemed to be more stabilising towards prey populations, with refuge occurring for prey at low prey densities (Colton 1987; Hassell 1978). The fitting of FR models allow parameters of interest to be estimated that relate to predator foraging behaviour (Rogers 1972; Jeschke et al. 2002). In that context, the attack rate is the scaling coefficient that corresponds to the initial slope of the curve (Hassell and May 1973), and therefore predators that consume more prey at low densities should have a higher attack rate. The handling time is a second parameter of interest for impact prediction, whereby predators with a lower handling time will reciprocally exhibit a higher maximum feeding rate (FR curve height) towards prey (Jeschke et al. 2002). 
Whilst the utility of FRs in predictions of ecological impact towards single prey species have been recurrently displayed (see before), there has hitherto been limited consideration for impacts towards more diverse prey communities, which represents a key context-dependency (Cuthbert et al. 2018, 2019a; Joyce et al. 2019). Prey switching (i.e. frequencydependent predation) could enhance impact predictions from comparative FRs, and is characterised by disproportionately reduced consumption where prey are rare and disproportionately high consumption where prey are abundant (Murdoch 1969). A form of frequency-dependent predation, prey switching by predators thus has the potential to stabilise prey populations by providing rare prey with refuge from predation (Hughes and Croy 1993). Classical work found prey switching behaviours in predatory fish that were disproportionately influenced by the abundance of spatially-partitioned benthic and surface prey within aquatic environments (Murdoch et al. 1975). On the other hand, prey populations may be destabilised (i.e. extirpated) when switching is not evidenced and predation is consistent towards one prey species irrespective of environmental abundance (Cuthbert et al. 2018). That is because consumption remains elevated towards a particular prey type, even when that prey is rare in the environment, threatening population persistence. Thus, incorporating quantitative assessments to determine evidence for prey switching, or lack thereof, for existing and emerging IAS may provide important insights for the prediction of ecological impacts, and in turn inform their management and mitigation.

A notorious marine IAS is Pterois volitans, the red lionfish (hereafter, lionfish), which has rapidly invaded the Caribbean Sea and western Atlantic Ocean (Albins and Hixon 2011). Lionfish are a commercially-available aquarium fish species globally, and as a result, were the first marine invaders to establish an invasive population resulting from the aquarium trade (Betancur et al. 2011). More recently, an incipient Mediterranean invasion from Lessepsian migrants via the Suez Canal has occurred, with six countries in the Mediterranean basin now invaded by $P$. volitans and related species $P$. miles (AndradiBrown 2019). Their ecological impacts on prey species can be severe, but these impacts are characterised by variability that thus far has been unexplained (Albins and Hixon 2011; Ingeman et al. 2017;
Hackerott et al. 2017), and thus may benefit from investigation with respect to per capita and prey switching propensities under key context-dependencies such as prey community diversity.

Juvenile lionfish are a particularly understudied IAS demographic, leading to a gap in the literature compared to that of adults (South et al. 2017) and that may contribute to the impact variability mentioned above. Adults ontogenetically switch to piscivorous feeding, which has implications for fisheries management in invaded areas (Morris and Akins 2009); however, juveniles are critical due to their feeding on planktonic species such as larval fish and crustaceans (Cure et al. 2012). This could lead to competition between juvenile lionfish and native fish species for prey, posing another threat, while further enhancing lionfish impacts. There is a distinct lack of quantification of juvenile lionfish ecological impact in marine ecosystems, due to their ability to avoid detection and capture at small sizes. Juvenile lionfish, below $15 \mathrm{~cm}$ are notably absent in the trophic ecology literature, despite the well recorded size-dependent differences in available gut content data (for size-dependent trophic ecology at $15 \mathrm{~cm}$ and above, see Dahl et al. 2014; Muñoz et al. 2011; Mizrahi et al. 2017; Dahl et al. 2017). Regardless, even within these size classes, smaller lionfish diet was composed of $62 \%$ invertebrates in Bacalar, Mexico (Dahl et al. 2017) and crustacean prey volume in lionfish gut contents drove the highest percentage difference between small and large lionfish diets on hard bottomed reefs in the USA (Muñoz et al. 2011).

Given their fast growth rate, cryptic nature (Darling et al. 2011), undetectable chemical scent (Lönnstedt and McCormick 2013) and size-dependent refuge from mechanical removal (Barbour et al. 2010), there is a potential that juvenile lionfish are exerting undocumented ecological impact upon prey species in their invasive ranges. However, observed lionfish impacts also seem to vary widely and there is debate as to their true ecological effects (Albins and Hixon 2011; Ingeman et al. 2017; Hackerott et al. 2017). Therefore, this presents a critical need to investigate the predatory impact, specifically of juvenile lionfish, towards a variety of prey types, with a focus on invertebrates such as crustaceans (Chagaris et al. 2017). In the present study, we thus quantify predatory impacts of juvenile lionfish in simple and marginally more complex experimental prey communities, asking 
whether their ecological impacts are mediated by per capita effects and frequency-dependent predation where multiple prey species occur. We thus first determine and compare the FRs and associated parameters of lionfish towards three prey species, Artemia salinas, Palaemonetes varians and Gammarus oceanicus, when individual prey species are presented at different densities, using the classic attack rate $(a)$ and handling time $(h)$, as well as the new functional response ratio $(a / h)$. Secondly, we examine whether lionfish exhibit prey switching behaviour when presented with multiple prey species simultaneously at different prey ratios, i.e. frequency-dependent predation.

\section{Materials and methods}

Animal collection and maintenance

Experiments were undertaken at Queen's Marine Laboratory (QML), Portaferry, Northern Ireland, between February and September 2018. Juvenile lionfish $(n=14$; mean total length $\mathrm{mm} \pm \mathrm{SE}$ : $7.87 \pm 1.29 \mathrm{~cm}$ ) from Grosvenor Tropicals, Lisburn, were kept in a holding tank (W: $12.6^{\prime \prime} \times \mathrm{L}$ : $\left.60^{\prime \prime} \times \mathrm{H}: 18^{\prime \prime}, 220 \mathrm{~L}\right)$ with external filtration containing UV- and sand-filtered Strangford Lough water. Predators used were of a similar size as the mass of predators relative to prey can influence predatory impact (Holling 1964). The water was changed daily and maintained at $25.0\left( \pm 1.0^{\circ} \mathrm{C}\right)$ using an aquarium heater under a natural light regime. Lionfish were maintained daily ad libitum on frozen anchovy to avoid predator learning behaviour to the focal experimental representative prey species. Feeding experiments were conducted within a glass tank (W: $\left.13^{\prime \prime} \times \mathrm{L}: 18^{\prime \prime} \times \mathrm{H}: 12^{\prime \prime}, 45 \mathrm{~L}\right)$ maintained at 25.0 $\left( \pm 1.0^{\circ} \mathrm{C}\right)$. All fish were allowed to acclimate to experimental arenas for $30 \mathrm{~min}$ prior to experimentation.

Prey species used for the experiments were brine shrimp (Artemia salina), dwarf white shrimp (Palaemonetes varians) and a marine gammarid (Gammarus oceanicus). Prey species were chosen to be taxonomically relevant but also available easily in high quantities (See Chagaris et al. 2017 for dietary importance of crustaceans for lionfish). In this case, A. salina represents small pelagic crustacean prey
(Dahl et al. 2017). Palaemonentes varians represents palaemonid shrimp, species of which are abundant across the lionfish invasive range and represented widely in lionfish diets (Layman and Allgeier 2012; Layman et al. 2014). In addition, their native range includes the North-East Atlantic and West Mediterannean (Falciai 2001) which may be subject to lionfish invasion commensurate with range expansion under thermal change. Gammarus oceanicus represents benthic crustacean prey species, such as amphipods and isopods, both found in lionfish diets in their invasive range (Morris and Akins 2009; Ortiz et al. 2015). Further, Gammarus oceanicus is native across the North Atlantic, and whilst lionfish have not established further north than Cape Hatteras, they have been detected as far as New York. Therefore, it is not unlikely that with warming scenarios their invasive range will overlap with that of G. oceanicus and similar species (Meister et al. 2005; Grieve et al. 2016; Pinsky et al. 2020). However, we note that these prey do not currently overlap with lionfish distributions.

All prey species were purchased from Seahorse Aquarium, Dublin, and maintained under identical conditions to the predators in separate holding tanks $\left(\mathrm{W}: 6^{\prime \prime} \times \mathrm{L}: 8^{\prime \prime} \times \mathrm{H}: 7^{\prime \prime}, 10 \mathrm{~L}\right)$. Intraspecific prey size was standardised throughout all trials (total length $\mathrm{mm} \pm \mathrm{SE}:$ A. salina $6.2 \pm 0.8 \mathrm{~mm} ; \quad P$. varians $10.9 \pm 0.7 \mathrm{~mm}$ and $G$. oceanicus $10.9 \pm 0.8 \mathrm{~mm}$ ). Pilot trials were carried out to determine appropriate prey densities for use during the experiments such that the FR type and asymptote could be determined (see Alexander et al. 2012). We complied with all necessary ethical protocols sought from the School of Biological Sciences ethics committee, Queen's University Belfast.

Functional responses

Each prey species was, separately, supplied at 16 densities per $45 \mathrm{~L}$ tank $(2,4,6,8,12,16,20,25,30,35$, $40,45,50,55,60,70 ; n=7$ per prey species per density; $0.04-1.56$ ind. $\mathrm{L}^{-1}$ ) in a randomised pattern temporally to eliminate time as a confounding factor. Functional response experiments were initiated through the addition of the allotted prey density to experimental tanks containing an individual lionfish. Lionfish were then allowed to feed for $3 \mathrm{~h}$ before being removed for enumeration of prey consumed. In total, 14 lionfish were used, with no lionfish used more 
than once at any prey density and prey species to avoid pseudoreplication. Reuse of individuals was, however, essential due to limited numbers of fish available (see Alexander et al. 2014). All individual lionfish had three days of recovery time between experiments. Controls consisted of one replicate of each prey type across all densities in the absence of lionfish predators.

\section{Prey switching}

Owing to similarities in body size and consumption rates by lionfish in FR trials (see later), $P$. varians and G. oceanicus were selected as prey types for the prey switching experiment. Palaemonetes varians and $G$. oceanicus were supplied to the lionfish at nine different prey ratios per $45 \mathrm{~L}$ tank $(45: 5,40: 10$, $35: 15,30: 20,25: 25,20: 30,15: 35,10: 40,5: 45 ; n=7$ per prey ratio; 1.1 ind. $\mathrm{L}^{-1}$ ). Lionfish were then allowed to feed for $1 \mathrm{~h}$ and all prey were replaced as they were consumed to maintain nominal prey species ratios throughout each replicate. Due to the logistics of the experiment, prey were replaced manually by the authors. Although this process of replacing prey may have resulted in some physical disturbance and increased visibility of added prey, we believe such effects would have been minor and well-balanced between prey types.

\section{Statistical analyses}

All statistical analyses were undertaken in R (R Core Development Team 2018). Logistic regression was used to deduce FR types based on analyses of proportional prey consumption across prey densities, with 'prey density' included as a continuous variable (Pritchard et al. 2017). Here, a significantly negative first-order term is indicative of a Type II FR (Juliano 2001). A significantly positive first order term followed by a significant negative second order term would indicate a Type III FR (Juliano 2001). To further illustrate the direction and shape of proportional consumption of prey at different prey densities, a locally weighted scatterplot smoothing, which had a smoothing factor of 6/10, was fit to the FR data for the three prey types (Pritchard et al. 2017). This smoothing indicated a Type II functional response given consumption rates decreased with increasing densities. As prey were not replaced as they were consumed, we therefore fit Rogers' random predator equation to model FRs (Rogers 1972):

$N_{e}=N_{0}\left(1-e x\left(a\left(N_{e} h-T\right)\right)\right)$

where $N_{\mathrm{e}}$ is the amount of prey consumed, $N_{0}$ is initial prey density, $a$ is the attack rate, $h$ is the handling time and $T$ is the total time available. We note that, at low prey densities, lionfish often consumed all available prey rapidly within the $3 \mathrm{~h}$ experimental period, and therefore our estimations of the attack rate parameter (i.e. FR initial slope) are likely conservative among prey types. Nonetheless, the random predator equation is robust to total prey depletion when estimating attack rates and handing times (Cuthbert et al. 2020). Further, in comparative FR analyses, it is the similarities and differences that are important rather than absolute values. Functional responses were then non-parametrically bootstrapped $(n=2000)$ to produce $95 \%$ confidence intervals using initial maximum likelihood estimates of $a$ and $h$. The indicator variable approach outlined in Juliano (2001) was used to determine differences between FR parameters ( $a$ and $h$ ) across prey types. The handling time parameter was then used to determine maximum feeding rates $(1 / h)$ of lionfish across prey types. Furthermore, the functional response ratio (FRR; $a / h$ ) was calculated for each prey type to amalgamate information from these two FR parameters (Cuthbert et al. 2019b; South et al. 2019). The FRR metric allows for comparative insights through synthesis of both FR parameters, resolving issues of which should be selected when determining ecological impacts by practitioners.

In the prey switching experiment, overall prey consumption was analysed using a generalised linear mixed model (Bates et al. 2015). Errors were assumed to be Poisson distributed given that prey were continually replaced, and were found not to be overdispersed through analysis of residual deviance. We incorporated 'prey species' (2 levels) and 'ratio' (9 levels) as fixed effects. To account for non-independence of data, each prey pair was included as a random effect in the model. In other words, because both prey types were presented simultaneously within the same experimental 'unit', with two separate prey mortality measures from each replicate, we captured this variation as a random intercept for each experimental unit, with random slopes for each prey type [i.e. $(1+$ preylunit)]. 
Chesson's selectivity index, assuming prey replacement, was used to infer prey preferences for $P$. varians and $G$. oceanicus across nominal ratios (Chesson 1978). Selection towards a particular prey types was determined by:

$\alpha_{i}=\left(r_{i} / n_{i}\right) / \sum_{j=1}^{m}\left(r_{j} / n_{j}\right)$

where $\alpha_{i}$ is Chesson's selectivity index for prey type $i$, $n_{i}$ is the number of prey type $i$ available at the start of the experiment, $r_{i}$ is the number of prey type $i$ consumed, $m$ the number of prey types, $r_{j}$ is the number of prey type $j$ consumed and $n_{j}$ the number of prey type $j$ available at the start of the experiment. In a two-prey system, values of $\alpha_{i}$ range between $0-1$, with 0.5 indicating null preference and those closer to 1 indicating increasing preference, whilst values closer to 0 indicate avoidance. Chesson's indices were transformed to reduce extremes $(0 \mathrm{~s}, 1 \mathrm{~s})$ :

$\alpha_{t}=\left(\alpha_{i}(n-1)+0.5\right) / n$

where $\alpha_{t}$ is the transformed output and $n$ is the sample size (Smithson and Verkuilen 2006). Beta regression was then used to compare between observed transformed Chesson's indices with those expected under null preference (0.5) (Cribari-Neto and Zeileis 2010). Here, 'observed/expected index' (2 levels) and 'ratio' (9 levels), for each reciprocated prey type were included as explanatory variables. We followed a backward stepwise deletion process in all models that omitted non-significant terms and interactions (Crawley 2007). Likelihood ratio tests were performed to derive the overall significance of effects. Where a factor was significant at the $95 \%$ confidence level, Tukey tests were employed post hoc for multiple pairwise comparisons (Lenth 2016).

\section{Results}

Across control groups for all prey species, survival exceeded $99 \%$ in the absence of lionfish Therefore, all mortality was assumed to be due to predation in the FR and switching experiments, and we observed predation events frequently.
Functional responses

First order terms were significantly negative, indicating Type II FRs by lionfish towards all prey species (Table 1; Fig. 1). Lionfish displayed the highest attack rate towards $A$. salina, intermediate rates upon $P$. varians and lowest towards G. oceanicus (Table 1). Attack rates towards A. salina were significantly higher compared to both $P$. varians $(z=13.56$, $p<0.001)$ and $G$. oceanicus $(z=43.69, p<0.001)$. In turn, $P$. varians had significantly greater attack rates than $G$. oceanicus $(z=3.96, p<0.001)$. Lionfish handling times were shortest towards A. salina, intermediate towards $P$. varians and longest towards G. oceanicus (Table 1). Handling times were significantly shorter towards A. salina than $P$. varians $(z=13.93, p<0.001)$ and $G$. oceanicus $(z=12.72$, $p<0.001)$, whilst the latter two species were not significantly different $(z=1.48, p=0.14)$. Accordingly, maximum feeding rates were highest towards $A$. salina, whilst feeding rates towards the other two prey species were more similar (Table 1; Fig. 2). Moreover, FRRs were highest towards $A$. salina, with $P$. varians intermediate and $G$. oceanicus lowest, illustrating the power of FRR to give better resolution of differences in per capita effects (Table 1).

Prey switching

Significantly more $P$. varians were consumed than $G$. oceanicus overall $\left(\chi^{2}=11.59\right.$, df $=1, p<0.001$; Fig. 3), and prey consumption was significantly greater where a given prey species was available at higher proportions $\left(\chi^{2}=681.29\right.$, df $\left.=8, p<0.001\right)$. However, there was a significant 'prey species $\times$ ratio' interaction $\left(\chi^{2}=44.36\right.$, df $\left.=8, p<0.001\right)$. This reflected greater dissimilarities in overall consumption in favour of $P$. varians when matched with $G$. oceanicus under higher proportions.

Lionfish exhibited a strong prey switching propensity between $P$. varians and G. oceanicus (Fig. 3). For both prey species, this was reflected by a significant interaction between 'observed/expected index' and 'proportion', signalling that observed Chesson's indices were variable as proportional availability changed for the prey species $\left(\chi^{2}=146.64\right.$, df $=8$, $p<0.001)$. For both prey species, selectivity was significantly lower than expected under null preference when present at low proportions $(0.1,0.2,0.3$, 
Table 1 First order terms, functional response (FR) types, rounded FR parameter estimates $(a, h$ and $1 / h)$ with associated $p$ values, alongside functional response ratio (FRR: $a / h$ ) estimates for all prey species treatments

\begin{tabular}{lllllll}
\hline Prey species & First order term, $p$ & FR Type & Attack rate $(a), p$ & Handling time $(h), p$ & Maximum feeding rate $(1 / h)$ & FRR $(a / h)$ \\
\hline A. salina & $-0.11<0.001$ & II & $13.595<0.001$ & $0.017<0.001$ & 56.97 & 774.47 \\
P. varians & $-0.07<0.001$ & II & $8.884<0.001$ & $0.025<0.001$ & 38.97 & 346.24 \\
G. oceanicus & $-0.06<0.001$ & II & $5.418<0.001$ & $0.027<0.001$ & 36.94 & 200.17 \\
\hline
\end{tabular}

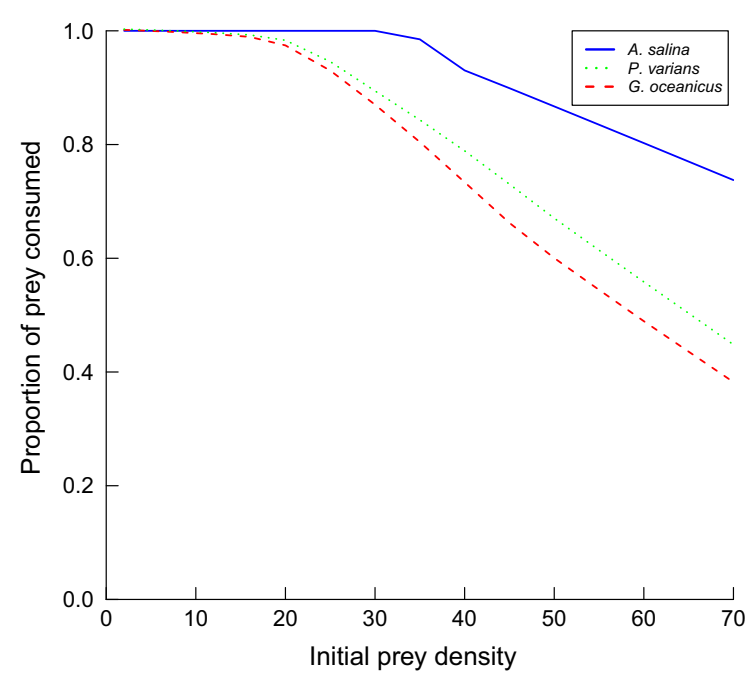

Fig. 1 Locally-weighted scatterplot smoothing lines fit to the proportion of prey consumed at each prey density for Artemia salina (blue, solid line), Palaemonetes varians (green, dotted line) and Gammarus oceanicus (red, dashed line)

0.4 ; all $p<0.01)$. Under equal proportions, selectivity towards prey did not deviate significantly from that expected $(0.5$; both prey species $p=0.31)$. When prey species were presented under higher proportions, observed selectivity was significantly higher than expected $(0.6,0.7,0.8,0.9$; all $p<0.01)$. Therefore, disproportionately less of a given species was consumed when presented under lower proportions, whilst, at higher proportions, disproportionately more of a given prey species was consumed than expected, i.e. prey switching occurred (Fig. 3).

\section{Discussion}

Predicting IAS ecological impacts remains a major challenge in conservation biology. While recent advances in predictive metrics have shown great

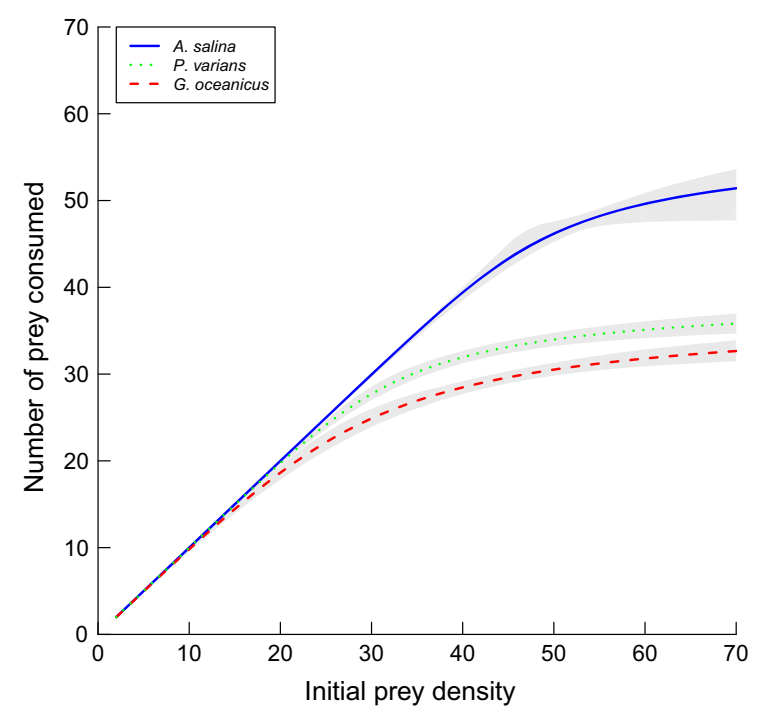

Fig. 2 Functional response curves for lionfish preying upon Artemia salina (blue, solid line), Palaemonetes varians (green, dotted line) and Gammarus oceanicus (red, dashed line). Shaded areas are $95 \%$ confidence intervals

promise in forecasting the impacts of invasive species (Dick et al. 2017a; Dickey et al. 2018), whether specific predatory effects are mediated by increasing prey diversity remains largely unexplored in invasion science (Cuthbert et al. 2018, 2019a). Here, we demonstrate that lionfish can exert substantial predation pressure on prey populations, using three representative macroinvertebrate species, due to potentially destabilising and high magnitude Type II predatory FRs. However, we also show that lionfish prey switching patterns in multiple species communities may somewhat ameliorate this ecological impact by generating low density prey refuge effects, although it should be caveated that factors such as prey traits also affect lionfish predation (Green and Côté 2014). Assessing prey consumption by lionfish through the use of FR and prey switching approaches thus serves 


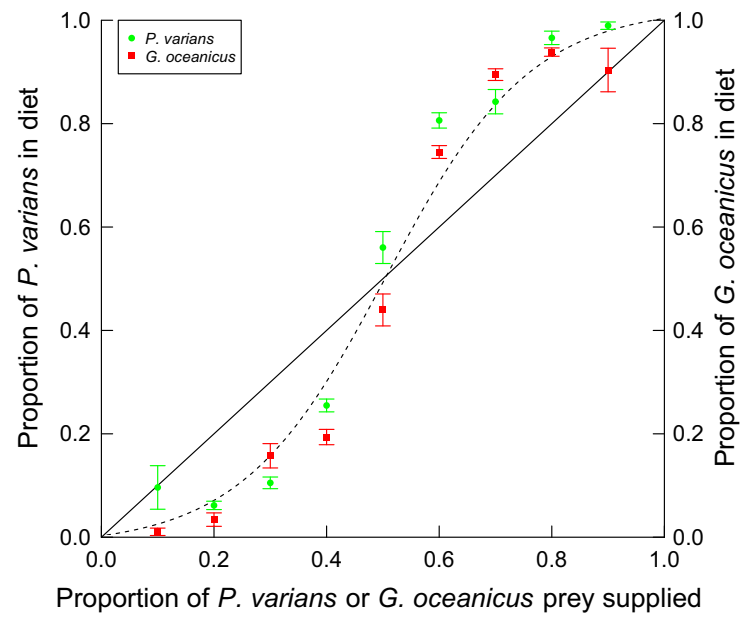

Fig. 3 Proportion of Palaemonetes varians (green, circle) or Gammarus oceanicus (red, square) in the diet of lionfish as a function of the proportion of each prey species supplied. The solid line indicates the expected values without preference between the prey, while the dashed (sigmoidal) line presents a hypothetical switching pattern. Means are $\pm \operatorname{SE}(n=7$ per prey species per nominal proportion). (Color figure online)

as an important step to improve our knowledge and predictions of the ecological impact and predatory capacity of this IAS. This is particularly timely as there is debate as to the reality of the ecological impacts conferred by lionfish, and emerging observations of large variation in such impacts (Albins and Hixon 2011; Ingeman et al. 2017; Hackerott et al. 2017). Whether effects found in the present study can be extended to other prey types (e.g. fishes) and in adult lionfish requires further examination.

Lionfish displayed Type II FRs towards all three representative prey species when each was presented separately, which might suggest destabilising effects towards prey populations due to high proportional consumption at low prey densities (Murdoch and Oaten 1975). However, Type II FRs tend to emerge when predators are unable to switch to alternative prey, and such switching may drive Type III FRs, which are more stabilising towards prey populations (see Dick et al. 2014). Our quantification of frequencydependent predation revealed that lionfish indeed demonstrate prey switching behaviour, which may result in low density refugia for prey species. Functional responses also tend to experimentally manifest as Type IIs, for example, as a result of lack of habitat complexity and arena size effects (Vucic-Pestic et al. 2010). Equally, we caution that the prey switching experiment conducted here may be subject to similar confinement effects that can alter the nature of predator-prey interactions, and particularly for ambush predators such as lionfish. Although, we note that the use of juveniles allowed for a relatively high search volume in aquaria, and we stress that our approach was a comparative laboratory-based study under standardised conditions for all organisms. Nevertheless, FR analyses and associated impact assessment metrics can be powerful indicators of per capita impacts and remain useful for comparative purposes (Dick et al. 2014, 2017b; Dickey et al. 2018). Considering prey switching propensities may further enhance these metrics (Cuthbert et al. 2019a), and demonstrating the propensity of a predator to exhibit switching may represent a species characteristic that is conserved across lab and field. However, switching studies could also be advanced further by being performed in the field, as has recently been proposed and applied for FR studies (e.g. Novak 2010; Novak et al. 2017). Moreover, our results may have been affected by intraspecific variation given that predators were reused in experiments; such phenomena could be tested using times between captures for individual predators in future works (Coblentz and DeLong 2020).

Lionfish predation and prey vulnerability to predation is mediated by prey trait combinations (Green and Côté 2014). Lionfish attack rates were significantly highest towards smaller-sized A. salina compared to larger-bodied $P$. varians and $G$. oceanicus, with $P$. varians intermediate. Active movement in the tank and prey size may thus be contributing factors to lionfish having higher attack rates on specific prey species, as visual fish predators find stationary prey less often than mobile prey (Uiblein et al. 1992). Furthermore, while nocturnal predators rely on chemical and hydromechanical cues (Wagner and Kröger 2000; Daghfous et al. 2012), lionfish are more reliant on visual cues to maximise hunting success as juveniles (Arias-González et al. 2011; Black et al. 2014; South et al. 2017). Lionfish are diurnal hunters in their invasive range, and therefore visual cues are important, indicating that reduced consumption of some species supplied may be due to small size which reduces detection. Future work should focus on using prey with a variety of functional traits which mediate vulnerability to predation in more complex settings to more realistically represent a reef community. 
When feeding on G. oceanicus, lionfish had similar handling times compared to $P$. varians, possibly due to both prey being similar in size. Whereas, when feeding on A. salina, a smaller prey, the lionfish had a significantly shorter handling time, and thus greater maximum feeding rate, compared to P.varians and $G$. oceanicus. Given that handling time increases concurrently with prey size, while attack rate is typically unimodal at intermediate relative predator-prey sizes (Brose 2010; McCoy et al. 2011), lionfish likely consumed fewer G. oceanicus prey given the longer period of time required to subdue and digest such prey items (Black et al. 2014; Pusack et al. 2016; Davis 2018). Our assimilation of the attack rate and handling time parameters into the FRR $(a / h)$ further demonstrates differential interaction strength between the prey species in a manner not immediately deductible from traditional FR curves alone (Cuthbert et al. 2019b; South et al. 2019). Whilst the FRR metric cannot distinguish between whether or not the attack rate or handling time drive differences in FRs, it allows for a simplified metric for practitioners to discern invader impact. That is because the attack rate and handling time can often be opposing in their trends (e.g., one species may simultaneously have higher attack rates and higher handling times than another), indicating high and low impact simultaneously. Synthesising these parameters thus allows for their influence to be balanced, and resolves issues of which parameter should be used to compare ecological impact. Using this method, we saw the highest FRR towards A. salina, followed by $P$. varians and $G$. oceanicus, and thus per capita effects are more clearly discriminated when FRR is applied, given their similar handling times.

Previous studies have shown that juvenile lionfish feed predominantly on small reef fishes and small crustaceans, with a dietary shift where fish prey become more important with increasing lionfish size (Valdez-Moreno et al. 2012; Mizrahi et al. 2017; Dahl et al. 2017; Sancho et al. 2018). Therefore, there are implications for a potential bentho-pelagic decoupling, manifested as the exchange of energy or nutrients between benthic and pelagic habitats (Griffiths et al. 2017). The results of the present study thus may impact fisheries management under invasion scenarios, as the presence of frequency-dependent predation (here, prey switching) suggests that species rich areas could confer a degree of lionfish predation refuge. However, future research should ascertain whether adult lionfish stages also exhibit a switching propensity between fish prey, as well as whether our results hold in field-based conditions that are not subject to any confinement effects. Further, the potential of some predatory fish to feed on adult and juvenile lionfish and therefore exert biotic resistance requires examination (Raymond et al. 2014).

The switching experiment shows that juvenile lionfish may enable frequency-dependent prey refuges, and this in turn may prevent local extirpations of prey species in biodiverse areas. While predation was, again, significantly higher towards $P$. varians overall, both prey species benefited from a low-density refuge, whereby significantly fewer prey were consumed than expected based on their frequency in the environment. Indeed, Hackerott et al. (2017) showed no evidence of a negative effect on native species on the Belize barrier reef by lionfish, and this may also be explained by prey switching behaviours resulting in a lack of serious impact. An avoidance of rare prey in more diverse environments may enable prey species persistence in areas of high species richness. Similarly, the findings of Peake et al. (2018) on lionfish feeding ecology concluded they are opportunistic generalists, consuming both vertebrate and invertebrate species across many trophic guilds. These predatory effects of lionfish may become more apparent at different densities depending on the reef diversity and habitat (Green and Côté 2014).

Switching propensities found in the present study may also have been influenced by differential spatial occupancies of prey in aquaria, with $P$. varians observed to be an active swimmer and G. oceanicus primarily benthic. In these cases, lionfish may have focused their efforts on parts of the water column where the most abundant prey occurred, in turn causing disproportionate consumption. Indeed, prey position in the water column has been found to facilitate prey switching in guppies, with predatory fish disproportionately targeting either surface-dwelling and benthic prey, depending on which was most abundant in the aquaria (Murdoch et al. 1975). Nonetheless, our results provide novel evidence for prey switching in a notorious IAS that may alleviate ecological impact should the trends be representative of the wild. We therefore suggest further empirical work to examine prey switching in more realistically complex settings. 
This study shows, for the first time, that lionfish exhibit prey switching when supplied with multiple prey items. However, their high maximum feeding rate capacity means they have the potential to confer high ecological impacts on individual prey species, even though model prey were used in the present study. Lionfish are somewhat philopatric (Tamburello and Côté 2015) and cause patch reef depletion, severely reducing local prey populations. This could likely be affected by further abiotic contexts, such as temperature and habitat complexity, as well as biotic factors such as lionfish learning behaviours regarding food (South et al. 2017; DeRoy et al. 2020a, b). While FR experiments alone are useful in ecological impact quantifications, when used in tandem with prey switching experiments, they can better inform predictions by offering insight into interaction strengths within species-rich communities. This study shows the potential to predict and understand the dynamics of invasion impact by combining these methods, which may help management develop strategies to mitigate further impacts of lionfish on native biota (MalpicaCruz et al. 2016). Effective fisheries management and protected areas promote biodiverse and functionally diverse reef communities which increases the relative abundance of a variety of prey species, and potentially enables prey switching. If this is twinned with intensive mechanical removal, the abundance of lionfish may be decreased, thus lowering total impact. We thus predict that lionfish impacts are marked in simple communities, but their effects are alleviated by prey switching when multiple resources are available. Additional laboratory and field experiments should be considered alongside comparative FR approaches to capture effects of diverse prey assemblages and aid future IAS management strategies. Furthermore, FR and prey switching methods could be combined to further inform impact predictions, by simultaneously altering prey density and prey species richness.

Acknowledgements We extend thanks to Mrs Emma Healey for assistance with experimental set-up.

Authors' contribution MM and JTAD conceived the study. MM and NM performed the experiments. MM, JS and RNC conducted statistical analyses. MM wrote the first draft and all authors contributed to revised versions and gave approval for submission.
Funding $M M$ is part funded from $G$ \& $M$ Williams fund, Queen's Marine Laboratory, Portaferry. JS acknowledges funding by the National Research Foundation (NRF) - South African Research Chairs Initiative of the Department of Science and Innovation (DSI)Technology (Inland Fisheries and Freshwater Ecology, Grant No. 110507) and the DSI-NRF Centre of Excellence for Invasion Biology (CIB). RNC acknowledges funding through a Research Fellowship from the Alexander von Humboldt Foundation. JWED is funded by Inland Fisheries Ireland.

Data availability Underlying raw data will be made available in the Supplementary Material.

\section{Compliance with ethical standards}

Conflict of interest The authors declare that they have no conflicts of interest.

Consent for participate The authors declare that they consent to participate.

Consent for publication The authors declare that they consent to the manuscript being published.

Ethics approval Ethical approval for work with lionfish was granted by the School of Biological Sciences Animal Research Ethics Committee, Queen's University Belfast.

Open Access This article is licensed under a Creative Commons Attribution 4.0 International License, which permits use, sharing, adaptation, distribution and reproduction in any medium or format, as long as you give appropriate credit to the original author(s) and the source, provide a link to the Creative Commons licence, and indicate if changes were made. The images or other third party material in this article are included in the article's Creative Commons licence, unless indicated otherwise in a credit line to the material. If material is not included in the article's Creative Commons licence and your intended use is not permitted by statutory regulation or exceeds the permitted use, you will need to obtain permission directly from the copyright holder. To view a copy of this licence, visit http://creativecommons.org/licenses/by/4.0/.

\section{References}

Albins M, Hixon M (2011) Worst case scenario: potential longterm effects of invasive predatory lionfish (Pterois volitans) on Atlantic and Caribbean coral-reef communities. Environ Biol Fishes 96:1151-1157

Alexander ME, Dick JTA, O'Connor NE, Haddaway NR, Farnsworth KD (2012) Functional responses of the intertidal amphipod Echinogammarus marinus: effects of prey supply, model selection and habitat complexity. Mar Ecol Prog Ser 468:191-202. https://doi.org/10.3354/meps09978

Alexander ME, Dick JTA, Weyl OLF, Robinson T, Richardson D (2014) Existing and emerging high impact invasive 
species are characterized by higher functional responses than natives. Biol Let 10:20130946. https://doi.org/10. 1098/rsbl.2013.0946

Andradi-Brown DA (2019) Invasive Lionfish (Pterois volitans and P: miles): Distribution, Impact, and Management. Mesophot Coral Ecosyst. https://doi.org/10.1007/978-3319-92735-0_48

Arias-González JE, González-Gándara C, Luis Cabrera J, Christensen V (2011) Predicted impact of the invasive lionfish Pterois volitans on the food web of a Caribbean coral reef. Environ Res 111:917-925. https://doi.org/10. 1016/j.envres.2011.07.008

Barbour AB, Montgomery ML, Adamson AA, Diaz-Ferguson E, Silliman BR (2010) Mangrove use by the invasive lionfish (Pterois volitans). Mar Ecol Progress Ser 401:291-294. https:// doi.org/https://doi.org/10.3354/ meps08373.

Bates D, Maechler M, Bolker BM, Walker SC (2015) Fitting linear mixed-effects models using lme4. J Stat Softw 67:1-48

Betancur-R R, Hines A, Acero PA, Ortí G, Wilbur AE, Freshwater DW (2011) Reconstructing the lionfish invasion: insights into Greater Caribbean biogeography. J Biogeogr 38:1281-1293. https://doi.org/10.1111/j.1365-2699.2011. 02496.x

Black AN, Weimann SR, Imhoff VE, Richter ML, Itzkowitz M (2014) A differential prey response to invasive lionfish, Pterois volitans: prey naiveté and risk-sensitive courtship. J Exp Mar Biol Ecol 460:1-7. https://doi.org/10.1016/j. jembe.2014.06.002

Briski E, Gollasch S, David M, Linley RD, Casas-Monroy O, Rajakaruna H, Bailey SA (2015) Combining ballast water exchange and treatment to maximize prevention of species introductions to freshwater ecosystems. Environ Sci Technol 49:1

Brose U (2010) Body-mass constraints on foraging behaviour determine population and food-web dynamics. Funct Ecol 24:28-34. https://doi.org/10.1111/j.1365-2435.2009. 01618.x

Chagaris D, Binion-Rock S, Bogdanoff A, Dahl K, Granneman J, Harris H, Mohan J, Rudd MB, Swenarton MK, Ahrens R, Patterson WF III, Morris JA Jr, Allen M (2017) An ecosystem-based approach to evaluating impacts and management of invasive lionfish. Fisheries 42:421-431. https://doi.org/10.1080/03632415.2017.1340273

Chesson J (1978) Measuring preference in selective predation. Ecology 59:211-215. https://doi.org/10.2307/1936364

Coblentz KE, DeLong JP (2020). Estimating predator functional responses using the times between prey captures. https:// doi.org/10.1101/2020.07.19.208686

Courchamp F, Clutton-Brock T, Grenfell B (1999) Inverse density dependence and the Allee effect. Trends Ecol Evol 14:405-410. https://doi.org/10.1016/s01695347(99)01683-3

Crawley MJ (2007) The R book. John Wiley, Chichester, pp 27-32

Cribari-Neto F, Zeilis A (2010) Beta regression in R. J Stat Softw 34:1-24

Cure K, Benkwitt CE, Kindinger TL, Pickering EA, Pusack TJ, McIlwain JL, Hixon MA (2012) Comparative behaviour of red lionfish Pterois volitans on native Pacific versus invaded Atlantic coral reefs. Mar Ecol Prog Ser 467:181-192. https://doi.org/10.3354/meps09942

Cuthbert RN, Dickey JWE, McMorrow C, Laverty C, Dick JTA (2018) Resistance is futile: lack of predator switching and a preference for native prey predict the success of an invasive prey species. R Soc Open Sci 5:180-339. https://doi.org/ 10.1098/rsos.180339

Cuthbert RN, Callaghan A, Dick JTA (2019a) Biotic resistance from native predators predicts mosquito invasion success and informs biocontrol strategies. Sci Rep 9:15314. https:// doi.org/10.1038/s41598-019-51705-9

Cuthbert RN, Dickey JWE, Coughlan NE, Joyce PWS, Dick JTA (2019b) The Functional Response Ratio (FRR): advancing comparative metrics for predicting the ecological impacts of invasive alien species. Biol Invas 21:2543-2547. https://doi.org/10.1007/s10530-01902002-z

Cuthbert RN, Wasserman RJ, Dalu T, Kaiser H, Weyl OLF, Dick JTA, Sentis A, McCoy MW, Alexander ME (2020) Influence of intra- and interspecific variation in predatorprey body size ratios on trophic interaction strengths. Ecol Evol 10:5946-5962. https://doi.org/10.1002/ece3.6332

Cuthbert RN, Pattison Z, Taylor NG, Verbrugge L, Diagne C, Ahmed DA, Leroy B, Angulo E, Briski E, Capinha C, Catford JA, Dalu T, Essl F, Gozlan RE, Haubrock PJ, Kourantidou M, Kramer AM, Renault D, Wasserman RJ, Courchamp F (2021) Global economic costs of aquatic invasive alien species. Sci Tot Environ (in press)

Daghfous G, Green WW, Zielinski BS, Dubuc R (2012) Chemosensory-induced motor behaviours in fish. Curr Opin Neurobiol 22:223-230. https://doi.org/10.1016/j.conb. 2011.10.009

Dahl KA, Patterson WF (2014) Habitat-specific density and diet of rapidly expanding invasive Red Lionfish, Pterois volitans, populations in the northern Gulf of Mexico. PLoS ONE 9:e105852. https://doi.org/10.1371/journal.pone. 0105852

Dahl KA, Patterson WF, Robertson A, Ortmann A (2017) DNA barcoding significantly improves resolution of invasive lionfish diet in the Northern Gulf of Mexico. Biol Invas 19:1917-1933. https://doi.org/10.1007/s10530-017-14073

Darling E, Green S, O’Leary J, Côté IM (2011) Indo-Pacific lionfish are larger and more abundant on invaded reefs: a comparison of Kenyan and Bahamian lionfish populations. Biol Invasions 13:2045-2051. https://doi.org/10.1007/ s10530-011-0020-0

Davis A (2018) Differential effects of native vs. invasive predators on a common Caribbean reef fish. Environ Biol Fishes 101:1537-1548. https://doi.org/10.1007/s10641018-0798-z

DeRoy E, Hussey NE, MacIsaac HJ (2020a) Behaviourallymediated learning ability in an invasive marine fish. Biol Invasions 22:3357-3369. https://doi.org/10.1007/s10530020-02329-y

DeRoy E, Scott N, Hussey NE, MacIsaac HJ (2020b) Density dependence mediates the ecological impact of an invasive fish. Divers Distrib 26:867-880. https://doi.org/10.1111/ ddi. 13063

Dick JTA, Alexander ME, Jeschke JM, Ricciardi A, MacIsaac HJ, Robinson TB, Kumschick S, Weyl OLF, Dunn AM, 
Hatcher MJ, Paterson RA, Farnsworth KD, Richardson DM (2014) Advancing impact prediction and hypothesis testing in invasion ecology using a comparative functional response approach. Biol Invas 16:735-753. https://doi.org/ 10.1007/s10530-013-0550-8

Dick JTA, Alexander ME, Ricciardi A, Laverty C, Downey PO, Xu M, Jeschke JM, Saul WC, Hill MP, Wasserman RJ, Barrios-O'Neill D, Weyl OLF, Shaw RH (2017a) Functional responses can unify invasion ecology. Biol Invas 19:1667-1672. https://doi.org/10.1007/s10530-016-13553

Dick JTA, Laverty C, Lennon JJ, Barrios-O’Neill D, Mensink PJ, Britton R, Médoc V, Boets P, Alexander ME, Taylor NG, Dunn AM, Hatcher MJ, Rosewarne PJ, Crookes S, MacIsaac HJ, Xu M, Ricciardi A, Wasserman RJ, Ellender BR, Weyl OLF, Lucy FE, Banks PB, Dodd JA, MacNeil C, Penk MR, Aldridge DC, Caffrey JM (2017b) Invader Relative Impact Potential: a new metric to understand and predict the ecological impacts of existing, emerging and future invasive alien species. J Appl Ecol 54:1259-1267. https://doi.org/10.1111/1365-2664.12849

Dickey JWE, Cuthbert RN, Rea M, Laverty C, Crane K, South J, Briski E, Chang X, Coughlan NE, MacIsaac HJ, Ricciardi A, Riddell GE, Xu M, Dick JTA (2018) Assessing the relative potential ecological impacts and invasion risks of emerging and future invasive alien species. NeoBiota 40:1-24. https://doi.org/10.3897/neobiota.40.28519

Didham RK, Tylianakis JM, Gemmeli NJ, Rand TA, Ewers RM (2007) Interactive effects of habitat modification and species invasion on native species decline. Trends Ecol Evol 22:489-496. https://doi.org/10.1016/j.tree.2007.07.001

Falciai L (2001) Occurrence of Palaemonetes varians (Leach, 1814) (Decapoda, Palaemonidae) in a brackish pond in Algeria. Crustaceana 74:697-701

Green SJ, Côté IM (2014) Trait-based diet selection: prey behaviour and morphology predict vulnerability to predation in reef fish communities. J Anim Ecol 83:1451-1460. https://doi.org/10.1111/1365-2656.12250

Grieve BD, Curchitser EN, Rykaczewski RR (2016) Range expansion of the invasive lionfish in the Northwest Atlantic with climate change. Mar Ecol Prog Ser 546:225-237. https://doi.org/10.3354/meps11638

Griffiths JR, Kadin M, Nascimento FJA, Tamelander T, Törnroos A, Bonaglia S, Bonsdorff E, Brüchert V, Gårdmark A, Järnström M, Kotta J, Lindegren M, Nordström M, Norkko A, Olsson J, Weigel B, Žydelis R, Blenckner T, Niiranen S, Winder M (2017) The importance of benthic-pelagic coupling for marine ecosystem functioning in a changing world. Glob Change Biol 23:2179-2196. https://doi.org/ 10.1111/gcb.13642

Hackerott S, Valdivia A, Cox CE, Silbiger NJ, Bruno JF (2017) Invasive lionfish had no measurable effect on prey fish community structure across the Belizean Barrier Reef. Peer J 5:3270. https:/doi.org/https://doi.org/10.7717/peerj.3270

Hassell MP (1978) The dynamics of arthropod predator-prey systems. Princeton University Press, Princeton, NJ

Hassell MP, May RM (1973) Stability in insect host-parasite models. J Anim Ecol 42:693-726. https:/doi.org/https:// doi.org/10.2307/3133

Haubrock PJ, Turbelin AJ, Cuthbert RN, Novoa A, Angulo E, Ballesteros-Mejia L, Bodey TW, Capinha C, Diagne C,
Essl F, Golivets M, Kirichenko N, Kourantidou M, Leroy B, Renault D, Taylor N, Verbrugge L, Courchamp F (2020). Economic costs of invasive alien species across Europe. NeoBiota (in press)

Holling CS (1959) Some characteristics of simple types of predation and parasitism. Can Entomol 91:385-398. https://doi.org/10.4039/Ent91385-7

Holling CS (1964) The analysis of complex population processes. Can Entomol 96:335-347. https://doi.org/10.4039/ Ent96335-1

Hoxha T, Crookes S, Lejeusne C, Dick JTA, Chang X, Bouchemousse S, Cuthbert RN, MacIsaac HJ (2018) Comparative feeding rates of native and invasive ascidians. Mar Pollut Bull 135:1067-1071. https://doi.org/10.1016/j. marpolbul.2018.08.039

Hughes RN, Croy MI (1993) An experimental analysis of frequency-dependent predation (switching) in the 15-spined stickleback, Spinachia spinachia. J Anim Ecol 62:341-352. https://doi.org/10.2307/5365

Iacarella JC, Dick JTA, Alexander ME, Ricciardi A (2015) Ecological impacts of invasive alien species along temperature gradients: testing the role of environmental matching. Ecol Appl 25:706-716. https://doi.org/10.1890/ 14-0545.1

Ingeman, K. E., Albins, M. A., Benkwitt, C. E., Green, J., Kindinger, T. L., Tuttle, L. J. and Hixon, M. A. (2017). Resolving differences in observed impacts of invasive lionfish and clarifying advice to managers. Peer Journal 5, 34-55. https:/doi.org/https://doi.org/10.7287/peerj. preprints.3455v1

IPBES (2019). Summary for policymakers of the global assessment report on biodiversity and ecosystem services of the Intergovernmental Science-Policy Platform on Biodiversity and Ecosystem Services, 86-101.

Jeschke JM, Kopp M, Tollrian R (2002) Predator functional responses: discriminating between handling and digesting prey. Ecol Monogr 72:95-112. https://doi.org/10.1890/ 0012-9615(2002)072[0095:PFRDBH]2.0.CO;2

Jeschke JM, Bacher S, Blackburn TM, Dick JTA, Essl F, Evans T, Gaertner M, Hulme PE, Kuhn I, Mrugala A, Pergl J, Pysek P, Rabitsch W, Ricciardi A, Richardson DM, Sendek A, Vila M, Winter M, Kumschick S (2014) Defining the impact of non-native species. Conserv Biol 28:1180-1194. https://doi.org/10.1111/cobi.12299

Joyce PWS, Dickey JWE, Cuthbert RN, Dick JTA, Kregting L (2019) Using functional responses and prey switching to quantify invasion success of the Pacific oyster, Crassostrea gigas. Mar Environ Res 145:66-72. https://doi.org/10. 1016/j.marenvres.2019.02.010

Juliano SA (2001) Nonlinear curve fitting predation and functional response curves. In: Scheiner S, Gurevitch J (eds) Design and analysis of ecological experiments. Oxford University Press, Oxford, pp 178-196

Layman CA, Allgeier JE (2012) Characterizing trophic ecology of generalist consumers: a case study of the invasive lionfish in The Bahamas. Mar Ecol Prog Ser 448:131-141. https://doi.org/10.3354/meps09511

Layman CA, Jud ZR, Nichols P (2014) Lionfish alter benthic invertebrate assemblages in patch habitats of a subtropical estuary. Mar Biol 161:2179-2182 
Lenth R (2016) Least-squares means: the R Package lsmeans. J Stat Softw 69:1-33. https://doi.org/https://doi.org/10. 18637/jss.v069.i01

Lönnstedt OM, McCormick MI (2013) Ultimate predators: lionfish have evolved to circumvent prey risk assessment abilities. PLoS ONE 8:757-781. https://doi.org/10.1371/ journal.pone.0075781

Lowry E, Rollinson EJ, Laybourn AJ, Scott TE, Aiello-Lammens ME, Gray SM, Mickley J, Gurevitch J (2013) Biological invasions: a field synopsis, systematic review, and database of the literature. Ecol Evol 3:1835-1835. https:// doi.org/10.1002/ece3.431

Malpica-Cruz L, Chaves LCT, Côté IM (2016) Managing marine invasive species through public participation: Lionfish derbies as a case study. Mar Policy 74:158-164. https://doi.org/10.1016/j.marpol.2016.09.027

McCoy MW, Bolker BM, Warkentin KM, Vonesh JR (2011) Predicting Predation through Prey Ontogeny Using SizeDependent Functional Response Models. Am Nat 177:752-766. https://doi.org/10.1086/659950

Meister HS, Wyanski DM, Loefer JK, Ross SW, Quattrini AM, Sulak KJ (2005) Further evidence for the invasion and establishment of Pterois volitans (Teleostei: Scorpaenidae) along the Atlantic Coast of the United States. Southeast Nat 4:193-206

Mizrahi M, Chapman JK, Gough CLA, Humber F (2017) Management implications of the influence of biological variability of invasive lionfish diet in Belize. Aquat Invas 8:61-70. https://doi.org/10.3391/mbi.2017.8.1.06

Morris JA, Akins JL (2009) Feeding ecology of invasive lionfish (Pterois volitans) in the Bahamian archipelago. Environ Biol Fishes 86:389-398. https://doi.org/10.1007/s10641009-9538-8

Morrison WE, Hay ME (2011) Herbivore Preference for Native vs. Exotic Plants: Generalist Herbivores from Multiple Continents Prefer Exotic Plants That Are Evolutionarily Naïve. PLoS ONE 6:72-77. https://doi.org/10.1371/ journal.pone.0017227

Muhlfeld CC, Kovach RP, Jones LA, Al-Chokhachy R, Boyer MC, Leary RF, Lowe WH, Luikart G, Allendorf FW (2014) Invasive hybridization in a threatened species is accelerated by climate change. Nat Clim Chang 4:620-624. https://doi.org/10.1038/nclimate2252

Muñoz RC, Currin CA, Whitfield PE (2011) Diet of invasive lionfish on hard bottom reefs of the Southeast USA: insights from stomach contents and stable isotopes. Mar Ecol Prog Ser 432:181-193. https://doi.org/10.3354/ meps09154

Murdoch WW (1969) Switching in general predators: experiments on predator specificity and stability of prey populations. Ecol Monogr 39:335-354. https://doi.org/10.2307/ 1942352

Murdoch WW, Oaten A (1975) Predation and population stability. Adv Ecol Res 9:1-131. https://doi.org/10.1016/ S0065-2504(08)60288-3

Murdoch WW, Avery A, Smyth MEB (1975) Switching in predatory fish. Ecology 56:1094-1105. https://doi.org/10. 2307/1936149

Novak M (2010) Estimating interaction strengths in nature: experimental support for an observational approach. Ecology 91:2394-2405. https://doi.org/10.1890/09-0275.1
Novak M, Wolf C, Coblentz KE, Shepard ID (2017) Quantifying predator dependence in the functional response of generalist predators. Ecol Lett 20:761-769. https://doi.org/ 10.1111/ele.12777

Ortiz M, Rodriguez-Zaragoza F, Hermosillo-Nuñez B, Jordán F (2015) Control strategy scenarios for the alien lionfish Pterois volitans in Chinchorro Bank (Mexican Caribbean): Based on semi-quantitative loop analysis. PLoS ONE 10:e130261. https://doi.org/10.1371/journal.pone. 0130261

Peake J, Bogdanoff A, Layman C, Castillo B, Reale-Munroe K, Chapman J, Dahl K, Patterson W III, Eddy C, Ellis R, Faletti M, Higgs N, Johnston M, Muñoz R, Sandel V, Villasenor-Derbez J, Morris J (2018) Feeding ecology of invasive lionfish (Pterois volitans and Pterois miles) in the temperate and tropical western Atlantic. Biol Invas 20:2567-2597. https://doi.org/10.1007/s10530-018-17205

Pinsky ML, Selden RL, Kitchel ZJ (2020) Climate-driven shifts in marine species ranges: Scaling from organisms to communities. Ann Rev Mar Sci 12:153-179. https://doi. org/10.1146/annurev-marine-010419-010916

Piria M, Copp GH, Dick JTA, Duplić A, Groom Q, Jelić D, Lucy FE, Roy HE, Sarat E, Simonović P, Tomljanović T, Tricarico E, Weinlander M, Adámek Z (2017) Tackling invasive alien species in Europe II: threats and opportunities until 2020. Manag Biol Invas 8:273-286. https://doi. org/10.3391/mbi.2017.8.3.02

Pritchard DW, Paterson RA, Bovy HC, Barrios-O'Neill D (2017) Frair: an R package for fitting and comparing consumer functional responses. Methods Ecol Evol 8:1528-1534. https://doi.org/10.1111/2041-210X.12784

Pusack T, Benkwitt CE, Cure K, Kindinger TL (2016) Invasive Red Lionfish (Pterois volitans) grow faster in the Atlantic Ocean than in their native Pacific range. Environ Biol Fishes 99:571-579. https://doi.org/10.1007/s10641-0160499-4

R Core Development Team (2018) R: a language and environment for statistical computing. R Foundation for Statistical Computing, Vienna, Austria

Raymond WW, Albins MA, Pusack T (2014) Competitive interactions for shelter between invasive Pacific red lionfish and native Nassau grouper. Environ Biol Fishes 98:57-65. https://doi.org/10.1007/s10641-014-0236-9

Rayner MJ, Gaskin CP, Fitzgerald NB, Baird KA, Berg MM, Boyle D, Joyce L, Landers TJ, Loh GG, Maturin S, Perrimen L, Scofield RP, Simm J, Southey I, Taylor GA, Tennyson AJD, Robertson BC, Young M, Walle R, Ismar SMH (2015) Using miniaturised radio telemetry to discover the breeding grounds of the endangered New Zealand storm petrel Fregetta maoriana. IBIS 157:754-766. https://doi. org/10.1111/ibi.12287

Ricciardi A (2003) Predicting the impacts of an introduced species from its invasion history: an empirical approach applied to zebra mussel invasions. Freshw Biol 48:972-981. https://doi.org/10.1046/j.1365-2427.2003. 01071.x

Rogers D (1972) Random search and insect population models. J Anim Ecol 41:369-383. https://doi.org/10.2307/3474

Sancho G, Kingsley-Smith PR, Morris JA, Toline CA, McDonough V, Doty SM (2018) Invasive Lionfish (Pterois 
volitans/miles) feeding ecology in Biscayne National Park, Florida, USA. Biol Invas 20:2343-2361. https://doi.org/10. 1007/s10530-018-1705-4

Seebens H, Blackburn TM, Dyer EE, Genovesi P, Hulme PE, Jeschke JM, Pagad S, Pyšek P, van Kleunen M, Winter M, Ansong M, Arianoutsou M, Bacher S, Blasius B, Brockerhoff EG, Brundu G, Capinha C, Causton CE, CelestiGrapow L, Dawson W, Dullinger S, Economo EP, Fuentes N, Guénard B, Jäger H, Kartesz J, Kenis M, Kühn I, Lenzner B, Liebhold AM, Mosena A, Moser D, Nentwig W, Nishino M, Pearman D, Pergl J, Rabitsch W, Rojas-Sandoval J, Roques A, Rorke S, Rossinelli S, Roy HE, Scalera R, Schindler S, Štajerová K, Tokarska-Guzik B, Walker K, Ward DF, Yamanaka T, Essl F (2018) Global rise in emerging alien species results from increased accessibility of new source pools. Proc Natl Acad Sci 111:2263-2274. https://doi.org/10.1073/pnas.1719429115

Simberloff D (2011) How common are invasion-induced ecosystem impacts? Biol Invas 13:1255-1268. https://doi. org/10.1007/s10530-011-9956-3

Simberloff D, Martin JL, Genovesi P, Maris V, Wardle DA, Aronson J, Courchame F, Galil B, Garcia-Berthou E, Pascal M, Pysek P, Sousa R, Tabacchi E, Vila M (2013) Impacts of biological invasions: what's what and the way forward. Trends Ecol Evol 28:58-66. https://doi.org/10. 1016/j.tree.2012.07.013

Smithson M, Verkuilen J (2006) A better lemon squeezer: Maximum-likelihood regression with beta-distributed dependent variables. Psychol Methods 11:54-71. https:// doi.org/10.1037/1082-989X.11.1.54

South J, Dick JTA, McCard M, Barrios-O'Neill D, Anton A (2017) Predicting predatory impact of juvenile invasive lionfish (Pterois volitans) on a crustacean prey using functional response analysis: effects of temperature, habitat complexity and light regimes. Environ Biol Fishes 100:1155-1165. https://doi.org/10.1007/s10641-0170633-y

South J, McCard M, Khosa D, Mofu L, Madzivanzira TC, Dick JTA, Weyl OLF (2019) The Effect of prey identity and substrate type on the functional response of a globally invasive crayfish. NeoBiota 52:9-24. https://doi.org/10. 3897/neobiota.52.39245

Stuer-Lauridsen F, Drillet G, Hansen FT, Saunders J (2018) Same Risk Area: An area-based approach for the management of bio-invasion risks from ships' ballast water. Mar Policy 97:147-155. https://doi.org/10.1016/j.marpol. 2018.05.009

Tamburello N, Côté IM (2015) Movement ecology of IndoPacific lionfish on Caribbean coral reefs and its implications for invasion dynamics. Biol Invas 17:1639-1653. https://doi.org/10.1007/s10530-014-0822-y

Uiblein F, Eberstaller J, Packl M, Winkler H (1992) Effects of differential prey mobility on the foraging behaviour of a cyprinid fish, Vimba elongata. Ethol Ecol Evol 4:293-297

Valdez-Moreno M, Quintal-Lizama C, Gómez-Lozano R, García-Rivas MC (2012) Monitoring an alien invasion: DNA barcoding and the identification of lionfish and their prey on coral reefs of the Mexican Caribbean. PLoS ONE 7:36-66. https://doi.org/10.1371/journal.pone.0036636

Vucic-Pestic O, Birkhofer K, Rall BC, Scheu S, Brose U (2010) Habitat structure and prey aggregation determine the functional response in a soil predator-prey interaction. Pedobiologia 53:307-312. https://doi.org/10.1016/j. pedobi.2010.02.003

Wagner HJ, Kröger RHH (2000) Effects of long-term spectral deprivation on the morphological organization of the outer retina of the blue acara (Aequidens pulcher). Philos Trans R Soc Lond Ser B-Biol Sci 355:1249-1252. https://doi.org/ 10.1098/rstb.2000.0677

Zieritz A, Lopes-Lima M, Bogan AE, Sousa R, Walton S, Rahim KA, Wilson JJ, Ng PY, Froufe E, McGowan S (2016) Factors driving changes in freshwater mussel (Bivalvia, unionida) diversity and distribution in Peninsular Malaysia. Sci Total Environ 571:1069-1078. https://doi.org/10. 1016/j.scitotenv.2016.07.098

Publisher's Note Springer Nature remains neutral with regard to jurisdictional claims in published maps and institutional affiliations. 